\title{
Applying socially responsible entrepreneurship in tourism businesses
}

\author{
Milena Botlíková ${ }^{1, *}, J o s e f$ Botlík$^{2}$, and Jana Stuchlíková ${ }^{1}$ \\ ${ }^{1}$ Faculty of Philosophy and Science in Opava, Bezručovo nám. 14, 74601 Opava, Czechia \\ ${ }^{2}$ School of Business Administration in Karvina, Univerzitní nám. 1934/3, 73340 Karviná, Czechia
}

\begin{abstract}
The current global world is recording and progressively developing tourism industry by the expansion of hotels and catering facilities. The development of tourism is inextricably linked with positive impacts such as growth of employment, increase in business activities, etc. On the other hand, the connection between tourism and global problems has been actively discussed in recent years. With the development of tourism occurs to the congestion of destinations, globalization brings degeneration of national cultures, grow gas emissions, soil erosion and increased waste production. The research revealed that Czech citizens consider the accumulation of waste as one of the global problems right after the lack of drinking water. One possibility of effective management of corporate waste is the implementation of waste management strategy in the management of the company. Businesses should aim to reduce, sort and recycle. The aim of the article was to compare the development of waste production in the European Union and the Czech Republic in connection with tourism and to evaluate the approach of Czech hotel companies to the issue of waste management. On the basis of the analysis, it can be stated that the amount of waste is gradually increasing and the hotels have some reserves.
\end{abstract}

\section{Introduction}

As a result of globalization processes there is a dynamic development of tourism. His development is also influenced by the lifestyle of the population, the desire for knowledge, social statute or change of free time's fond. If we look at the definition Business for Social Responsibility [1], social responsibility is defined as: "Voluntary integration of social and environmental considerations into daily business operations and interactions with stakeholders." Sustainable tourism development is such „... which secures current needs of the participants of tourism and it concurrently helps of territory development"[2]. It is clear from the definitions that the sustainability of tourism development and corporate social

* Corresponding author: milena.botlikova@fpf.slu.cz 
responsibility are based on identical economic, social and environmental pillars [3]. From these definitions, it can be concluded that tourism enterprises (and not only them) should integrate the principles of corporate social responsibility into their business processes for sustainable development. CSR (Corporate Social Responsibility) represents concept, when the company takes co-responsibility for welfare and sustainable development, within their business activities. Concurrently, companies expect that they will keep competitiveness and economic profit, whereas profit making and CSR do not pursue conflicting goals, they incorporate the principles of sustainable development to operation, all with full volunteering. As far as the environmental point of view is concerned, unlike economic or social, it is mainly associated with negative impacts. The environmental issues of sustainable development and corporate social responsibility in the waste area relate to energy saving, water resources, waste, its sorting, and minimization, recycling or re-use. Everyone's priority goal, whether it be an individual, a company, or an entire company, waste management should be minimized. This minimization should precede all others ways of economy and waste management. Each business strategy should include a "3R" model (Reduce, Reuse, Recycle). The global benefit is not to generate waste.

Taking into account the careful use of natural resources and cultural values, it can be stated that tourism operators contribute to the long-term prosperity and attractiveness of the area. The attractiveness of the destination is influenced by approaches to waste [4], there is a non-linear and significant relationship of the arrival of tourists, expenditures on tourism specialization and tourism on municipal waste production [4]. Similarly, Boys et al. [5], appeals to the need to "respect the sustainability of the destination, since customers who want to travel are more environmentally friendly, and the introduction of environmental and social programs is one of the criteria for choosing accommodation".

Hotel and restaurant facilities are considered as highly polluting [6]. In the area of tourism in the area of hotel and restaurant facilities, these are primarily issues related to waste management, its controlled reduction, sorting, recycling, the use of environmentally friendly products and improved consumption planning, respecting the waste management economy of the given location, etc. [2]. Restaurants and hotels are one of the main producers of bio and municipal waste. (municipal waste is defined in more detail by law. The exact wording of the definition of "similar municipal waste" is based on Act 185/2001 Coll. Waste Act (2nd Directive of the European Parliament and of the Council 2008/98 / EC) [7].

Taking into account what activities are carried out in hotel and catering establishments, this is an extensive list of waste. These include, for example, procurement-related waste and technological food preparation processes, unused food, pizza boxes, glass and plastic from beverages and cosmetics, discarded furniture, office paper consumption, etc.). It is therefore mainly biological and municipal waste. Individual actions by businesses should reduce food waste. Incremental steps can eliminate unwanted food; up to $30 \%$ of the food that is thrown away in restaurants comes from customers' plates [8]. Increased food production has an impact on biodiversity worldwide. Another important step in environmental thinking is waste reduction through a change of approach. Restaurants and hotels offer a variety of delicacies, optimizing cleaning and washing products, etc.). As mentioned, it is best not to generate waste at all or to recycle or return it to use instead of incineration. An essential element in the reduction of municipal waste is employees and customers, who can also contribute to reducing the environmental burden of restaurants and hotels. The 'greening' of hotel operations in the context of CSR shows the close links between CSR and human resource management in hotels [9]. Branco et al. [10], says adopting CSR is responsible for increasing productivity, loyalty, reputation and long-term competitive advantage. 


\subsection{Methods and database}

There are a number of sets of indicators and criteria for assessing corporate social responsibility and sustainable business. The issue of waste management is part of many comprehensive indices and methodologies for assessing sustainable development or CSR. Within the evaluation of tourism sustainability at the regional level of the Czech Republic, one of the indicators of environmental evaluation is the amount of municipal waste. From the point of view of the tourism sustainability of destinations, according to the European System [11], these are waste management indicators for solid waste, the percentage of tourism enterprises sorting different types of waste (optional), the waste generated by the destinations year and month and volume of recycled waste (percentage or volume per inhabitant and year). According to Hajek [12], the proportion of recycled municipal waste is not an appropriate indicator of the transition to a circular economy. The amount of waste and the volume of waste transported (amount of loading) is also used by UNWTO [11]. Waste management is a part of company management environmental management system (EMS). EMS is currently the most widespread way an enterprise can claim to be committed to protecting the environment in its operations, in the production of products and services. This system can be implemented through EMAS or ISO 14001 [13]. Other indicators of environmental performance include the award of an eco-label. Eco-label management today is an example of innovative hotel management [14]. Environmental policy implements environmental protection, waste policy, recycling, above all, the integration of employees themselves into environmental thinking [11].

The article was used for the analysis of secondary information from information databases CENIA, OECD, EUROSTAT etc. The analysis certifications on the MRD indicator. In the absence of statistics on waste generation in enterprises (accommodation and catering), the research is based on the fact that in most cases these are commercial units whose waste is not different from the household, and most of these enterprises use a lot of municipal waste within the region. Access to waste management has been identified through a pilot questionnaire and eco-hotel certification (eco-label, eco-label), EMAS or ISO 14001 registration.

\section{Comparison development of municipal waste in the EU28 and the Czech Republic}

The World population in 2016 was produced $0.74 \mathrm{~kg} /$ person every day. Every year around 2.5 billion tonnes of waste (safe and hazardous) are produced in the EU, on average, 5.9 tonnes/day of waste were produced per capita in the EU in 2017 [15]. After a temporary period of decline in its production since 2008, it continues to grow waste. (Figure 1).
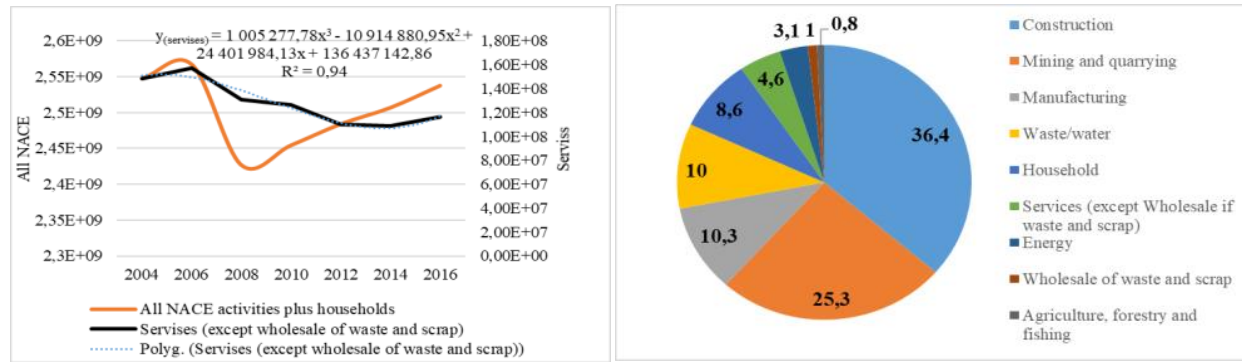

Fig. 1: Waste in EU and, Services share in total waste production 2017

Economic growth is reflected in waste management. Waste production has not declined in the long term due to consumer social behaviour. On the positive side, the continued increase in municipal waste recycling has pushed the EU towards the 2030 target [15]. 
The total amount of waste in the service sector also shows an increase after years of decline (Fig.1, [16]). According to the forecast, the amount of production in services will increase, but its increase is not a source of a sharp increase in the total amount of waste after 2008. As regards the share of waste generation by industry, the highest waste producer is the construction sector. Services accounted for $5.8 \%$ of waste production in 2004, and their share in the total amount of waste is gradually decreasing (except 2008; 6.1\%), up to $4.6 \%$ by 2016. The Czech Republic was producing for $0.91 \%$ (2016) of total EU waste (businesses and households) and $1.0 \%$ (2016) in the services sector, an increase of $0.24 \%$ compared to 2008 .

In the case of EU municipal waste (without mixed waste), the development of waste in the EU and the Czech Republic is not very different; both curves have the same trajectory. The development of municipal waste in the EU tends to be shown in Figure 2. Although municipal waste accounts for only $10 \%$ of total waste generation, households are the primary sources of waste. However, there are areas where high levels of municipal waste are caused by tourists in regions such as Cyprus, Malta or Croatia. According to figure 2, the regions of Denmark, Cyprus, Germany, Luxembourg or Malta have the highest proportion of municipal waste per capita in the EU per capita, which is not the dominant country in the number of domestic and foreign tourists staying in the COE in 2017. The Czech Republic was one of the regions of the EU with the lowest amount of municipal waste per capita. Arranged before Poland, Romania. The Czech Republic maintained its position from 2009.

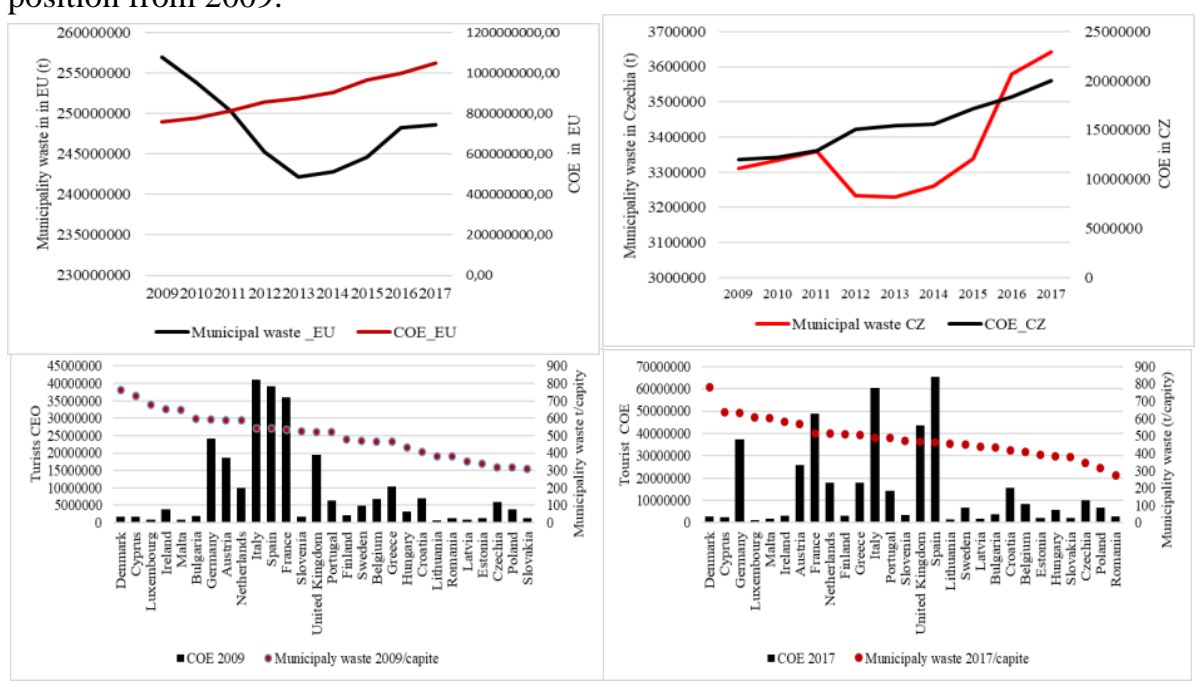

Fig. 2 Development of municipal waste in the service sector, in tones and in tones/capita

Like Arbula [4], we wondered if there was a relationship between the number of tourists in the region and the amount of municipal waste. They focused on finding relationships at the Czech level. A non-linear relationship was found between the number of tourists staying in collective accommodation facilities and the amount of municipal waste at the level of the Czech Republic. According to the model of the regression equation $(1,2)$, it is assumed that in the unchanged situation the municipal waste of the Czech Republic will increase in the future (minimum 14476458 tourists in CAE, Durbin Watson 2,41 sig. model $<0.05$, see Figure 3 ). One cause of waste growth may be an increase in tourism consumption after the 2013 crisis.

Which should lead to the efforts of all hoteliers to introduce within CSR into environmental principles into their management and implement EMS (EMAS, ISO 14001 and ecology's labels. A survey in 12 EU countries [17] showed that EMAS is one of the 
options to achieve the environmental target; most respondents attribute EMAS to improving the circular economy and waste.

\begin{tabular}{|c|c|c|c|c|c|}
\hline \multicolumn{6}{|c|}{ ANOVA } \\
\hline & $\begin{array}{l}\text { Sum of } \\
\text { Squares }\end{array}$ & df & Mean Square & $\mathrm{F}$ & Sig. \\
\hline Regression & $1,530 E+11$ & 2 & 76512203366 & 20,575 & .002 \\
\hline Residual & 22312482157 & 6 & 3718747026 & & \\
\hline Total & $1,753 \mathrm{E}+11$ & 8 & & & \\
\hline \multicolumn{6}{|c|}{ The independent variable is HUZCZ. } \\
\hline \multicolumn{6}{|c|}{ Coefficients } \\
\hline & \multicolumn{2}{|c|}{ Unstandardized Coefficients } & $\begin{array}{l}\text { Standardized } \\
\text { Coefficients }\end{array}$ & \multirow[b]{2}{*}{$t$} & \multirow[b]{2}{*}{ Sig. } \\
\hline & B & Std. Error & Beta & & \\
\hline HUZCZ &,- 412 & .100 & $-7,721$ & $-4,113$ & .006 \\
\hline HUZCZ $* 2$ & $1,423 \mathrm{E} \cdot 008$ & ,000 & 8,414 & & \\
\hline (Constant) & 6238856,731 & 773416,147 & & 8,067 & .000 \\
\hline
\end{tabular}

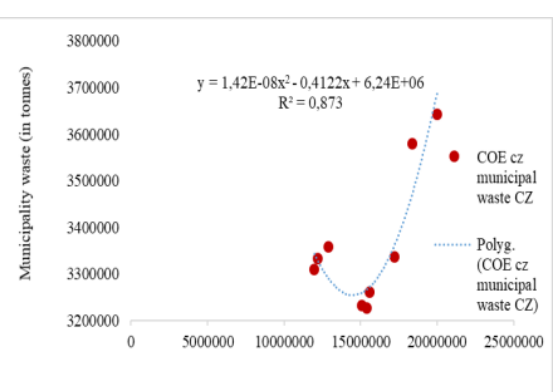

Fig. 3. Regression analysis

$$
\begin{gathered}
y=\beta_{0}+\beta_{1} x_{1}+\beta_{2} x_{2}+\varepsilon \\
y=6,24 E+06-4,12 E-01 x+1,42 E-08 x^{2}
\end{gathered}
$$

\subsection{Comparison of implementation of environmental management in hotel and restaurant facilities in the EU 28 and the Czech Republic}

If we consider that only those companies that have implemented EMAS systems, ISO 14001 standards or hold the certificate Eco-friendly service behave environmentally, then the situation in accommodation services and restaurants in the Czech Republic would be very poor. EMAS has not carried out any hotel or other accommodation and catering facilities (environmental statement verification). In contrast, in the EU there are 199 establishments in accommodation establishments in 2017 (2019; 187 establishments, (see table $1 ;[18]$ ). Hotels and catering facility in Czechia took advantage of the possibility to implement in their management in 2006 in nine cases of certification ISO 14001, a total of 2122 enterprises were registered, in 2017 there was a decrease ( 7 certifications), in all sectors increased (see tab. 1). They are mostly large businesses, hotel chains (for example Mc Donald). The most ISO 14001 certifications were awarded in 2017 in Spain (169) and Greece (116 companies, see fig. 4; [19]).

Regarding the award of eco-labels Flower, in 2017 (see figure 4) 454 accommodation establishments were registered in the EU, i.e. $20.95 \%$. Italy, France and Spain play the first place in the field of certification. Currently (2019) has 469 hotels listed. In the case of the Czech Republic, five hotel establishments were certified in 2017, which has been a decrease by two certifications since 2008. In 2019, only one company is registered on the Ecolabel website, namely the Centre of Environmental Education and Ethics RýchoryNORTH. According to fig. 4, it is clear that the scope of certified environmental accommodation services does not guarantee a low level of municipality waste per person.

Tab. 1. Potential to better integrate EMAS and ISO 14001 into existing policies to help public authorities achieve their environmental objectives in priority areas in 2017

\begin{tabular}{|l|c|c|c|c|}
\hline & EMAS $(\mathrm{H})$ & EMAS $*$ & ISO $14001(\mathrm{H})$ & ISO $14001 *$ \\
\hline EU28 & 187 & 3728 & 592 & 52870 \\
\hline Czechia & 0 & 20 & 7 & 3552 \\
\hline
\end{tabular}

*in all sectors

Another brand that can be acquired by accommodation and catering companies in the framework of the provision of services is the Czech eco-label "Green Eco-label". A total of 207 certifications were registered in 2009,7 related to hotels. Three of them also owned the 
Ecolabel certification EU Flower. The number of all sector registrations is decreasing (2017 - 51 registration); the decrease also applies to hotel facilities. In 2017 there were only three hotels [20].

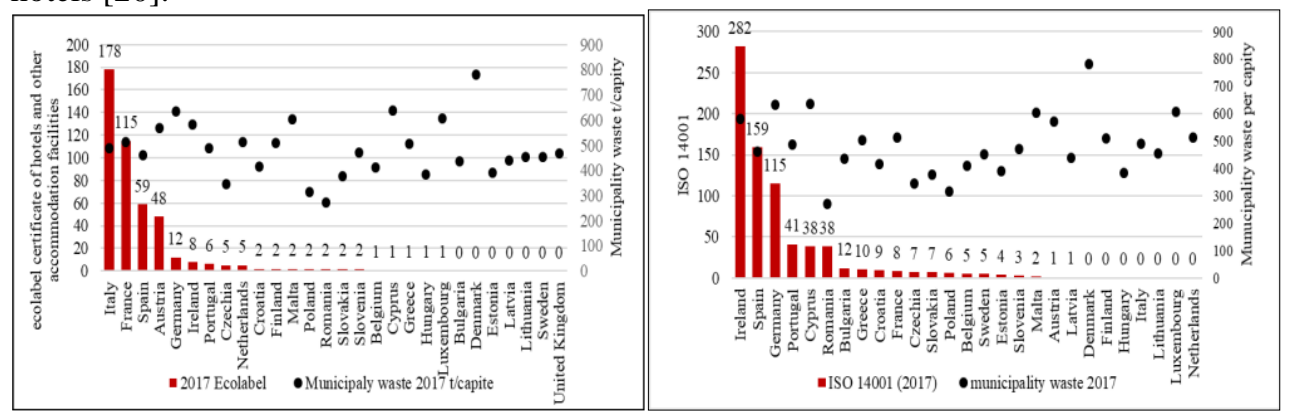

Fig. 4. Registration Ecolabel EU and ISO 14001 in NACE H - municipality waste in 2017

Do you environmentally friendly in Czech hotels? A total of 16 hotels were evaluated in the pilot survey. Research has shown that hotels are trying to solve the problems of waste management according to their own beliefs and possibilities. Among the hotels are of nonEMAS certified businesses. Internet information shows businesses that have permission to manage unnecessary certificates or standards, but when using environmentally friendly means intuitive and common sense. All hotel businesses sort waste, only one hotel is replied that it sorts partially. In most cases, waste is sorted in the background of the facility. Only one hotel reports that they are already sorting in hotel rooms. In two four-star hotels they are considering sorting waste in their rooms. The responses show that hotels recycle waste partially. Up to $50 \%$ do not recycle, $25 \%$ only partially and only two hotels report recycling. After consultation, however, it is mainly composting. As mentioned above, the reduction of the global problem should not be approached only by the subsequent treatment of waste but by an effort to prevent its generation. According to the piloting, it is clear that hotel companies are trying to effectively buy and train employees to use food effectively in preparation and cooking, but also to sort solid waste. The problem is that even though employees are trained, they do not adopt an ecological lifestyle. In two hotels, there was a problem with keeping the separation by type (plastic, paper, glass). The monitored enterprises are trying to refrain from disposable packaging of delicacies (mustard, ketchup, honey, etc.); disposable packaging uses very few devices. Also, disposable plastic dishes (plastic cups, paper trays) are minimally used (see http://pracres.eu/?page_id=428).

\section{Conclusion}

The results analysis show disparities between EU countries. In the Czech Republic, as in the EU28, the amount of municipal waste is growing. Poland and Romania are most to municipal production waste per capita. The Czech Republic has position above average between regions EU28, but municipal waste increases. Although there seems to be, a nonlinear relationship between collective accommodation facilities and the increases amount hotel water and energy consumption, as well as waste generation [21-22]. Companies have many options for adopting environmental management. One of them is the implementation of EMAS or the ISO 14001 standard. In Czech conditions, as in research [23], only a small proportion of small hotels in restaurants consider adopting sustainable solid waste management practices, although acceptance would be appropriate. The problem with the reluctance to register EMAS or ISO in the Czech Republic is in regulation. However, the Czech Environmental Regulatory Office declares more significant regulatory relief for registered EMAS. The advantage of registration is the administrative simplicity of reporting 
annual declarations. For enterprises with EMAS registration or ISO 14001 certification, it is sufficient to submit either an environmental statement or an EMS certificate. Undertakings without registration must specify a system for carrying out pollutant release and waste management and how to avoid environmental damage. ISO 14001 (including energy audit) or ISO 5001 certified companies do not need to perform an energy audit every four years. Also, the share of eco-labelled enterprises in the Czech Republic has been gradually decreasing. According to hotel research and information, hotel complexes are trying to take on corporate social responsibility, but are reluctant to invest time and money in certification and building a management system. Businesses usually implement a social responsibility policy to their best conscience. A systemic solution to corporate social responsibility is a step towards creating sustainable development. As stated by Frans Timmermans, President of the European Commission: "Our planet and our economy make it possible to survive if we further implement the take-and-throw approach."

This paper is an output of the science project SGS 2/2019 "Tourism of the Moravian-Silesian Region in the context of sustainable development" Faculty of Philosophy and Science in Opava.

\section{References}

1. M. Randle, et al. Making cause-related corporate social responsibility (CSR) count in holiday accommodation choice. Tourism Management, 6, 12 (2019)

2. MMR. Available from: http://www.mmr.cz/getmedia/cc80193b-e4e8-4694-8a65728df70a5fd8/GetFile14_2.pdf

3. V. Kunz. Společenská odpovědnost firem. (EDP Grada Publishing, 2012)

4. I. Arbulu, et al. Tourism and solid waste generation in Europe: A panel data assessment of the Environmental Kuznets Curve. Waste Management, 46, 9 (2015)

5. K. A. Boys, et al. Fostering rural and agricultural tourism: exploring the potential of geocaching. Journal of Sustainable Tourism, 25, 20 (2017)

6. F. Kř́žžek, J. Neufus. Moderní hotelový management. (EDP Grada Publishing, 2014)

7. Waste Act no. 185/2001 Sb. Available from: https://www.zakonyprolidi.cz/cs/2001185

8. Business Leaders Forum. Co je CRS. Available from: https://www.csr-online.cz/co-jecsr/14-otazek-a-odpovedi-o-csr/

9. P. Bohdanowicz, et al. International hotel chains and environmental protection: an analysis of Hilton's we care! Programme. (Europe, 2006-2008). Journal of Sustainable Tourism, 19, 20 (2011)

10. M. C. Branco, L. Rodrigues. Corporate social responsibility and resource-based perspectives. Journal of Business Ethic,s 69, 22 (2006)

11. Sustainable development in the European Union Monitoring report on progress towards the SDGs in an EU context. Available from: https://ec.europa.eu/eurostat/statisticsexplained/images/7/73/Waste_generation\%2C_2016_\%28kg_per_inhabitant\%29.png

12. Oběhové hospodářství: Jsme na něj připraveni?. Available from: https://euractiv.cz/section/energetika/linksdossier/obehove-hospodarstvi-jsme-na-nejpripraveni-000140/

13. A. Santamaria, R. Javier. The sectoral reference document for tourism in the European eco-management and audit scheme (EMAS). Actualidad Juridica Ambiental, 59, 15 (2016) 
14. R. Dziuba. Sustainable development of tourism - EU Ecolabel standards illustrated using the example of Poland. Comparative economic research-Central and Eastern Europe, 19, 18 (2016)

15. Eurostat. Available from: https://ec.europa.eu/eurostat/ https://ec.europa.eu/eurostat/statistics-explained/

16. Waste Management Plan of the Czech Republic 2015-2024. Available from: https://www.mzp.cz/cz/plan_odpadoveho_hospodarstvi_cr

17. Reinforcing Added Value for EMAS. Available from: https://ec.europa.eu/environment/emas/pdf/other/RAVE\%20final\%20report.pdf

18. Eurostat. Available from: https://ec.europa.eu/environment/emas/emas_registrations/statistics_graphs_en.htm

19. Survey ISO 14001. Available from: https://isotc.iso.org/livelink /livelink? func=ll\&objId=18808772\&objAction=browse \&viewType $=1$

20. Cenia. Available from: https://issar.cenia.cz/publikace-o-stavu-zivotnihoprostredi/statisticka-rocenka-zivotniho-prostredi-cr/

21. H. R. I. Radwan, et al. Managing solid waste in small hotels. Journal of sustainable tourism, 18, 16 (2010)

22. H. R. I. Radwan, et al. Solid waste management in small hotels: a comparison of green and non-green small hotels in Wales. Journal of Sustainable Tourism, 20, 18 (2012)

23. M.D. Seggara-One, et al. Does Environmental Certification Help the Economic Performance of Hotels? Evidence from the Spanish Hotel Industry. Cornell Hospitality Quarterly, 53, 15 (2011) 